\title{
Antimicrobial Activity and Chemical Composition Screening of Epilobium montanum Root
}

\author{
Kerem Canli ${ }^{1 *}$, Ali Yetgin ${ }^{2}$, Ilgaz Akata ${ }^{3}$, Ergin Murat Altuner ${ }^{4}$ \\ ${ }^{1}$ Department of Biology, Faculty of Science, Dokuz Eylül University, Izmir, TURKEY \\ ${ }^{2}$ Department of Biotechnology, Institute of Engineering and Science, Izmir Institute of Technology, Izmir, TURKEY \\ ${ }^{3}$ Department of Biology, Faculty of Science, Ankara University, Ankara, TURKEY \\ ${ }^{4}$ Department of Biology, Faculty of Science and Arts, Kastamonu University, Kastamonu, TURKEY
}

\begin{abstract}
Medical herbs have many bioactive component and they are used in microbial treatment since ancient time. The resistance of pathogen to antibiotic is became a critical problem, so novel antimicrobial agent related research is required. Epilobium montanum related antimicrobial research doesn't exist, therefore root of this medicinal plant investigation was applied against 17 bacteria and 1 fungi by using disk diffusion method. These microbial species include Bacillus, Enterobacter, Enterococcus, Escherichia, Klebsiella, Listeria, Pseudomonas, Salmonella, Staphylococcus and Candida genera. Besides, chemical composition of this sample was determined by Gas Chromatography-Mass Spectroscopy. The results were presented that $E$. montanum has antimicrobial activity against all tested microbial species except $E$. coli. Seventeen major chemical components were determined, but some composition of this sample is not match with library. For this reason, this medicinal plant contain unknown molecules and this molecules should be analysed by NMR spectra for 3D structure determination and identification.
\end{abstract}

Keywords: Epilobium montanum, Medicinal Plant, Antimicrobial Activity, Chemical Composition, Disk Diffusion Method, GC-MS.

\section{INTRODUCTION}

A tremendous progress in medicine has been observed especially at the last decades. But unfortunately microorganisms, including viruses, are still on the agenda of the scientist, because diseases caused by them are still threatening the public health especially in the developing countries, despite the remarkable progression in the medicine. ${ }^{1-3}$ The growing number of new resistant pathogens direct the researches to discover new antimicrobial agents inevitably. Plants are accepted to be good candidates of being sources for new drug hits.

Epilobium montanum, which is one of the willow herb species and commonly known as broad-leaved willow herb, is distributed in North, South and Central Anatolian region between $780 \mathrm{~m}-2300 \mathrm{~m}$ elevations. It is mostly found on the riversides in forests. ${ }^{4}$ It is known to be used as an ethno medicine especially against kidney, urinary tract and prostate diseases in Austria, but it also have some common uses around the world against urinary system and prostate problems. ${ }^{5-6}$ There are several researches about the anticancer properties of E. montanum. ${ }^{5}$ But the research about its antimicrobial activity is very limited according to the current literature.

The main purpose of this study was to investigate antimicrobial activity of E. montanum against 17 bacteria and 1 fungi and to determine its biochemical composition to contribute the literature with this information.
DOI: 10.5530/ijper.51.3s.21 Correspondence: Kerem Canli, Department of Biology, Faculty of Science, Dokuz Eylül University, Izmir, TURKEY

Phone no: +902323019543 E-mail: biyoloji@gmail.com 


\section{MATERIALS AND METHODS}

\section{Plant samples preparation}

E. montanum is medicinal plant was obtained from local market. $2.75 \mathrm{mg}$ and $9.17 \mathrm{mg}$ E. montanum samples were prepared with ethanol extraction process as mentioned in previous study. ${ }^{7}$

\section{Antimicrobial activity test}

17 bacteria and 1 fungi was used and sustained on Nutrient Agar (BD Difco, USA). Microorganism inoculum process was applied as done in previous study. ${ }^{8}$ The antimicrobial activity of E. montanum was performed by disk diffusion test.

\section{Gas chromatography-mass spectrophotometry method (GC-MS)}

For the identification of chemical components, each sample was analyzed by Shimadzu GCMS QP 2010 ULTRA equipped with RTX-5MS capillary column $(30 \mathrm{~m} * 0.25 \mathrm{~mm}$; coating thickness $0.25 \mu \mathrm{m})$. Analytical conditions were an injector temperature of $250{ }^{\circ} \mathrm{C}$; carrier gas Helium at $1.78 \mathrm{~mL} / \mathrm{min}$; injection mode: split, split ratio 10:1; volume injected: $1 \mu \mathrm{L}$ of sample in ethanol extract and oven temperature programmed from $40{ }^{\circ} \mathrm{C}$ to $290{ }^{\circ} \mathrm{C}$ at $4{ }^{\circ} \mathrm{C} / \mathrm{min}$, pressure: $100 \mathrm{kPa}$, total flow: $13.7 \mathrm{~mL} / \mathrm{min}$. The MS scan conditions were an interface temperature of $250{ }^{\circ} \mathrm{C}$, and an ion source temperature of $200{ }^{\circ} \mathrm{C}$. Identification of the components was conducted by matching the retention times against Wiley Data Library and crosscheck was applied with previously published data. ${ }^{10}$ The chemical components found to be higher than 1\% were accepted as the major components and the list of these components and information regarding them are given in Table 2.

\section{Controls}

Empty sterile disks and extraction solvent (ethanol) were used as negative controls.

\section{Statistics}

The statistical analysis was executed using a parametric method, the one-way analysis of variance (ANOVA), with a significance level of $0.05 .^{11}$ In order to put forward any correlation between concentration and antimicrobial activity Pearson correlation coefficient was calculated. ${ }^{12}$ All statistical analysis were conducted by using $\mathrm{R}$ Studio, version 3.3.2. ${ }^{13}$

\section{RESULTS AND DISCUSSIONS}

The diameter of these zones were measured in millimeters and given as mean values with standard errors in Table 1. No activities were observed for empty sterile disks and ethanol loaded disks, which are negative controls. Furthermore, statistical analysis proved that

\begin{tabular}{|l|c|c|}
\hline \multicolumn{3}{|c|}{ Table 1: Disk diffusion test result for Epilobium montanum (Inhibition zones in mm). } \\
\hline & $\mathbf{3 0 \mu \mathrm { L }}$ & $\mathbf{1 0 0 \mu \mathrm { L }}$ \\
\hline Bacillus subtilis DSMZ 1971 & $8,00 \pm 0,00$ & $11,00 \pm 0,00$ \\
\hline Candida albicans DSMZ 1386 & $11,00 \pm 0,71$ & $13,00 \pm 0,00$ \\
\hline Enterecoccus faecalis ATCC 29212 & - & $9,00 \pm 0,00$ \\
\hline Enterecoccus faecium & $17,00 \pm 0,71$ & $22,00 \pm 0,00$ \\
\hline Enterobacter aerogenes ATCC 13048 & - & $8,00 \pm 0,00$ \\
\hline Enterococcus durans & $7,00 \pm 0,00$ & $8,00 \pm 0,00$ \\
\hline Escherichia coli ATCC 25922 & - & - \\
\hline Klebsiella pneumonia & $12,00 \pm 0,71$ & $14,00 \pm 0,71$ \\
\hline Listeria innocua & - & $8,00 \pm 0,00$ \\
\hline Listeria monocytogenes ATCC 7644 & $11,00 \pm 0,00$ & $14,00 \pm 0,00$ \\
\hline Pseudomonas aeruginosa DSMZ 50071 & $16,00 \pm 0,00$ & $21,00 \pm 0,71$ \\
\hline Pseudomonas fluorescens P1 & $7,00 \pm 0,00$ & $9,00 \pm 0,00$ \\
\hline Salmonella enteritidis ATCC 13076 & $11,00 \pm 0,00$ & $14,00 \pm 0,00$ \\
\hline Salmonella infantis & - & $8,00 \pm 0,00$ \\
\hline Salmonella kentucky & $13,00 \pm 0,00$ & $15,00 \pm 0,00$ \\
\hline Salmonella typhimurium SL1344 & $18,00 \pm 0,00$ & $21,00 \pm 0,00$ \\
\hline Staphylococcus aureus ATCC 25923 & $15,00 \pm 0,00$ & $16,00 \pm 0,00$ \\
\hline Staphylococcus epidermidis DSMZ 20044 & $14,00 \pm 0,00$ & $17,00 \pm 0,71$ \\
\hline
\end{tabular}

"-":No inhibition 
Table 2: The major chemical components of Epilobium montanum.

\begin{tabular}{|c|c|c|c|c|c|}
\hline No & $\begin{array}{l}\text { Retention } \\
\text { Time }\end{array}$ & Compound name & Formula & $\begin{array}{c}\text { Molecular } \\
\text { Weight }(\mathrm{g} / \mathrm{mol})\end{array}$ & $\begin{array}{c}\text { Area } \\
(\%)\end{array}$ \\
\hline 1 & 27.875 & 1,2,3-Benzenetriol & $\mathrm{C}_{6} \mathrm{H}_{6} \mathrm{O}_{3}$ & 126.110 & 5.05 \\
\hline 2 & 42.864 & Neophytadiene & $\mathrm{C}_{20} \mathrm{H}_{38}$ & 278.516 & 2.65 \\
\hline 3 & 48.139 & Palmitic acid & $\mathrm{C}_{16} \mathrm{H}_{32} \mathrm{O}_{2}$ & 256.424 & 9.27 \\
\hline 4 & 53.563 & Phytol & $\mathrm{C}_{20} \mathrm{H}_{40} \mathrm{O}$ & 296.531 & 2.20 \\
\hline 5 & 54.331 & 9,12-Octadecadienoic acid (Z,Z)- & $\mathrm{C}_{18} \mathrm{H}_{32} \mathrm{O}_{2}$ & 280.445 & 2.25 \\
\hline 6 & 54.583 & 9,12,15-Octadecatrienoic acid, (Z,Z,Z)- & $\mathrm{C}_{18} \mathrm{H}_{30} \mathrm{O}_{2}$ & 278.430 & 8.04 \\
\hline 7 & 64.522 & Limonen-6-ol, pivalate & $\mathrm{C}_{15} \mathrm{H}_{24} \mathrm{O}_{2}$ & 236.350 & 1.45 \\
\hline 8 & 65.613 & Hexadecanoic acid, 2-hydroxy-1-(hydroxymethyl)ethyl ester & $\mathrm{C}_{19} \mathrm{H}_{38} \mathrm{O}_{4}$ & 330.503 & 1.11 \\
\hline 9 & 66.190 & Unknown & - & - & 2.71 \\
\hline 10 & 70.460 & 1-Heptacosanol & $\mathrm{C}_{27} \mathrm{H}_{56} \mathrm{O}$ & 396.733 & 14.97 \\
\hline 11 & 73.788 & Squalene & $\mathrm{C}_{30} \mathrm{H}_{50}$ & 410.718 & 1.01 \\
\hline 12 & 91.633 & gamma.-Sitosterol & $\mathrm{C}_{29} \mathrm{H}_{50} \mathrm{O}$ & 414.707 & 23.00 \\
\hline 13 & 92.619 & beta.-Amyrin & $\mathrm{C}_{30} \mathrm{H}_{50} \mathrm{O}$ & 426.717 & 1.09 \\
\hline 14 & 93.445 & Phytol, acetate & $\mathrm{C}_{22} \mathrm{H}_{42} \mathrm{O}_{2}$ & 338.568 & 1.97 \\
\hline 15 & 94.338 & METHYL COMMATE C & - & - & 1.39 \\
\hline 16 & 96.829 & .alpha.-Tocopheryl acetate & $\mathrm{C}_{31} \mathrm{H}_{52} \mathrm{O}_{3}$ & 472.743 & 1.37 \\
\hline 17 & 102.589 & Phytol, acetate & $\mathrm{C}_{22} \mathrm{H}_{42} \mathrm{O}_{2}$ & 338.568 & 1.07 \\
\hline
\end{tabular}

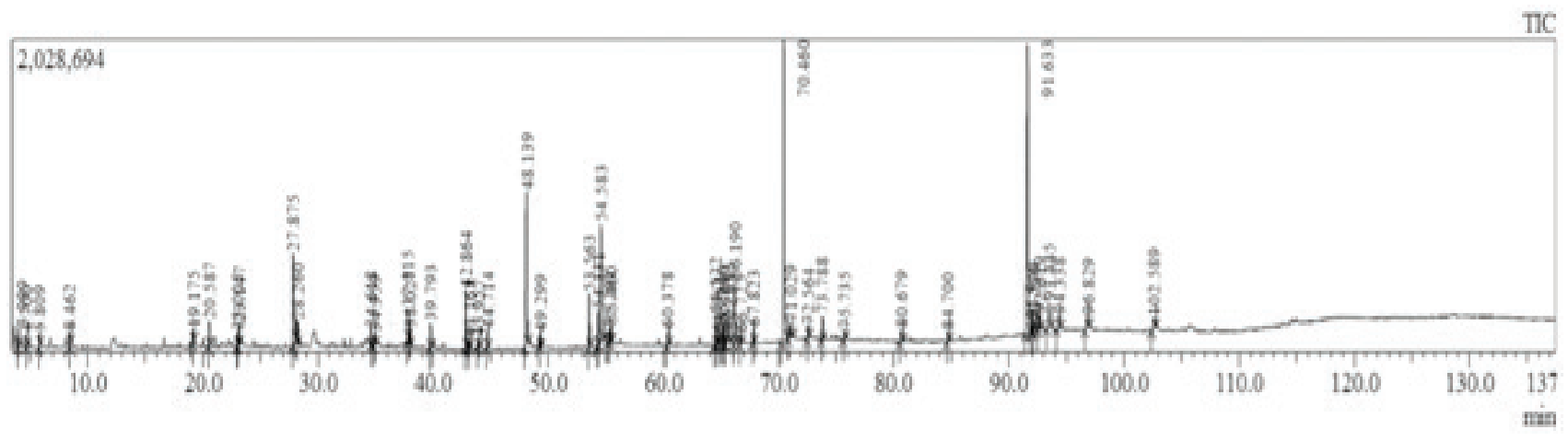

Figure 1: GC-MS chromatogram of Epilobium montanum.

there are no significant difference between the activities of three parallels of each extract volumes, which are 30 and $100 \mu \mathrm{L}$, with $p$ values of 0.9896 and 0.9983 respectively. On the other hand, the difference between the activities of two different extract volumes are observed to be statistically insignificant with a $p$ value of 0.09235 , which can be accepted as significant for $p$ value $<0.1$. In addition, a very weak positive correlation was observed between increasing the extract volume tested and the activity observed, where the Pearson correlation coefficient is 0.2847267 .

According to Table 1, E. montanum has antimicrobial activity against all tested microbial species except E. coli. 15 results were observed to be little effect, where
13 were weak, 5 were moderate and 3 were strong. ${ }^{14}$ The frequencies were given in Figure 1. These result are important because of being the first determination of the antimicrobial activity of E. montanum.

Gram negative bacteria have more resistance against aromatic plants than gram positive bacteria. The highest activity was reached against E. faecium $(22 \mathrm{~mm})$, S. typhimurium (21 $\mathrm{mm})$, P. aeruginosa $(21 \mathrm{~mm})$, S. epidermidis $(17 \mathrm{~mm}), S$. aureus $(16 \mathrm{~mm})$ and $S$. kentucky $(15 \mathrm{~mm})$ at $9.17 \mathrm{mg}$ ethanol samples. E. faecium, S. epidermidis and $S$. aureus are gram positive bacteria; $S$. typhimurium, $P$. aeruginosa and $S$. kentucky are gram negative bacteria. Therefore, E. montanum has approximately the same antimicrobial activity against gram positive and gram negative 
bacteria. This result demonstrate that E. montanum can be used for large range of microbial infection treatment.

According to the current literature the antimicrobial activity of E. montanum wasn't studied in details. Sheikh Akbari Mehr and Malekzadeh studied the antimicrobial activity of some Epilobium species against 7 bacteria by using disk diffusion test. ${ }^{15}$ There are some differences which could possibly depend on several reasons: (1) the location and collection time of E. montanum may change active components, (2) the amount of extracts tested on microorganisms may be different and (3) the type of extraction solvent may change the active compounds extracted from plant samples.

The GC-MS chromatogram is given in Figure 1 and according to Table 2 prepared according to the data in Figure 1; gamma.-Sitosterol (23.00\%), 1-Heptacosanol (14.97\%), Palmitic acid (9.27\%), 9,12,15-Octadecatrienoic acid, (Z,Z,Z)- (8.04\%), 1,2,3-Benzenetriol (5.05\%) are mainly found in the composition of E. montanum. These results are critical because of being the first identification of the biochemical composition of them by GC-MS.

\section{CONCLUSION}

E. montanum has antimicrobial activity against large range of microorganisms, but further researches are required in order to analysis their mechanisms. It contain some fatty acids in relatively high amounts, which are important for foodborne pathogen treatment. Its extract and compound will be used for industrial purposes in order to prevent contamination.

\section{ACKNOWLEDGEMENT}

None

\section{CONFLICT OF INTEREST}

None

\section{ABBREVIATION USED}

GC-MS: gas chromatography-mass spectrophotometry method; NMR: nuclear magnetic resonance; 3D: three dimensional.

\section{REFERENCES}

1. Agarwal A, Prajapati R, Raza SK, Thakur LK. GC-MS Analysis and Antibacterial Activity of Aerial Parts of Quisqualis indica Plant Extracts. Indian J Pharm Educ. 2017;51:329-36.

2. Powar TA, Hajare AA, Patil-Vibhute PB, Nadaf SJ, Jarag RJ. Bioadhesive Garlic and Ketoconazole Vaginal Tablets for Treatment of Candidiasis. Indian J Pharm Educ. 2017;51:239-48.

3. Cos P, Vlietinck AJ, Berghe DV, Maes L. Anti-infective potential of natural products: how to develop a stronger in vitro 'proof-of-concept'. J Ethnopharmacol. 2006;106(3):290-02.

4. TUBIVES Taken from: http://www.tubives.com/index.php?sayfa=1\&tax id=3879 Access date: 01.05.17

5. VogI S, Picker P, Mihaly-Bison J, Fakhrudin N, Atanasov AG, Heiss EH, Kopp B. Ethnopharmacological in vitro studies on Austria's folk medicine-An unexplored lore in vitro anti-inflammatory activities of 71 Austrian traditional herbal drugs. J Ethnopharmacol. 2013;149(3):750-71.

6. Granica S, Piwowarski JP, Czerwińska ME, Kiss AK. Phytochemistry, pharmacology and traditional uses of different Epilobium species (Onagraceae): A review. J Ethnopharmacol. 2014;156:316-46.

7. Canli K, Akata I, Altuner EM. In vitro antimicrobial activity screening of Xylaria hypoxylon. Afr J Tradit Complement Altern Med. 2016;13(4):42-6.

8. Canli K, Altuner EM, Akata I. Antimicrobial screening of Mnium stellare. Bangladesh J Pharmacol. 2015;10(2):321-5.

9. Canli K, Yetgin A, Akata I, Altuner EM. In vitro antimicrobial screening of Aquilaria agallocha roots. Afr $\mathrm{J}$ Tradit Complement Altern Med. 2016;13(5):178-81.

10. Canli K, Altuner EM, Akata I, Turkmen Y, Uzek U. In vitro antimicrobial screening of Lycoperdon lividum and determination of the ethanol extract composition by gas chromatography/mass spectrometry. Bangladesh $\mathrm{J}$ Pharmacol. 2016;11(2):389-94.

11. Chambers JM, Hastie TJ. Statistical Models in S, Wadsworth \& Brooks/Cole; 1992.

12. Becker RA, Chambers JM, Wilks AR. The New S Language. Wadsworth \& Brooks/Cole; 1988.

13. Core $R$ Team. R: A language and environment for statistical computing. $R$ Foundation for Statistical Computing, Vienna, Austria. URL https://www.Rproject.org/. 2016

14. Kim MJ, Lee SH, Cho JH, Kim MK, Lee HS. Growth responses of seven intestinal bacteria against Phellodendron amurense root-derived materials. J Microbiol Biotechnol. 2003;13(4):522-8.

15. Mehr SAR, Malekzadeh P. Antibacterial activity of some Epilobium L. species aerial parts extract. J Aquatic Ecol. 2015;5(1):68-2. 
PICTORIAL ABSTRACT

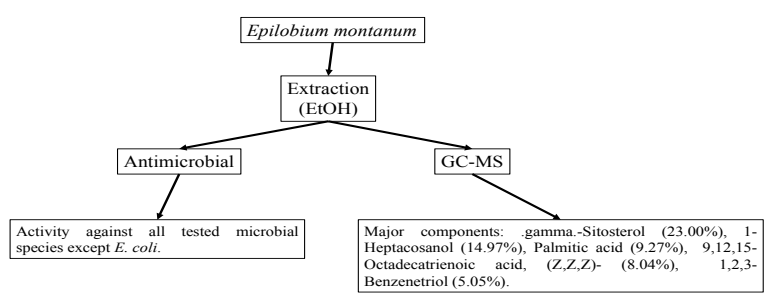

About Authors

\section{SUMMARY}

- The antimicrobial activity of Epilobium montanum was analysed against 17 bacteria and 1 fungi by using disk diffusion method.

- The test microorganisms included Bacillus, Enterobacter, Enterococcus, Escherichia, Klebsiella, Listeria, Pseudomonas, Salmonella, Staphylococcus and Candida genera.

- The chemical composition of this sample was determined by Gas Chromatography-Mass Spectroscopy.

- The extract was observed to be active against all tested microbial species except E. coli.

- The major chemical components were observed as gamma.-Sitosterol (23.00\%), 1-Heptacosanol (14.97\%), Palmitic acid (9.27\%), 9,12,15-Octadecatrienoic acid, (Z,Z,Z)- (8.04\%), 1,2,3-Benzenetriol $(5.05 \%)$, but somecomponents of this sample didn't match with the library.

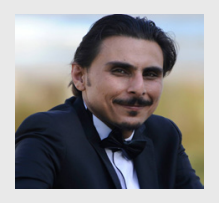

Kerem CANLI is working as an Assistant Professor in Dokuz Eylul University, Faculty of Science, Department of Biology, Izmir, TURKEY. He completed his B.Sc. and Ph.D. degree in Ankara University.

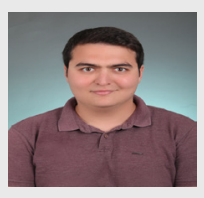

Ali YETGIN is completed his B.Sc. in Izmir Institute of Technology, Faculty of Science, Department of Molecular Biology, Izmir, TURKEY. He is now studying on his M.Sc. thesis.

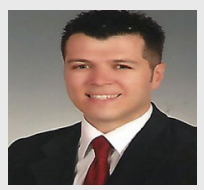

Ilgaz AKATA is working as an Associate Professor in Ankara University, Faculty of Science, Department of Biology, Ankara, TURKEY. He completed his B.Sc., M.Sc. and Ph.D. degree in Ankara University.

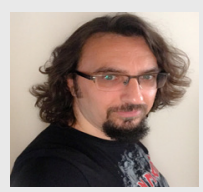

Ergin Murat Altuner is working as an Associate Professor in Kastamonu University, Faculty of Science and Arts, Department of Biology, Kastamonu, TURKEY. He completed his B.Sc. degree in Ankara University, M.Sc. degree in Middle East Technical University and Ph.D. degree in Ankara University.

Cite this article: Canli K, Yetgin A, Akata I, Altuner EM. Antimicrobial Activity and Chemical Composition Screening of Epilobium montanum Root. Indian J of Pharmaceutical Education and Research. 2017;51(3)Suppl:S239-43. 